\title{
Revista Brasileira de Fruticultura \\ Reaction of papaya genotypes to target spot and activity of plant extracts and Bacillus spp. on Corynespora cassiicola
}

\author{
Dannielle Silva da Paz ${ }^{1}$, José Ribamar Gusmão Araujo², Antônia Alice Costa Rodrigues ${ }^{3}$, \\ Erlen Keila Candido e Silva ${ }^{4}$, Nathália Bandeira Diniz ${ }^{5}$
}

\begin{abstract}
Papaya target-spot, caused by fungus Corynespora cassiicola presents a wide geographic distribution, causing leaf spots in several hosts. The aim of this research was to evaluate the behavior of papaya varieties and/or selections to the natural occurrence of target spot, and test the fungi toxic effect of neem, citronella and eucalyptus extracts, and fungi static effects of Bacillus isolates on the fungus $C$. cassiicola in vitro. To evaluate the natural occurrence of the disease in field, symptoms on leaves of 11 papaya varieties and/or selections have been assessed. The pathogenicity of isolates was verified by inoculation of plants in greenhouse. Neem, citronella and eucalyptus extracts were prepared at concentrations of 10,15 and $20 \%$ and poured into Petri dishes containing C. cassiicola mycelium discs. For Bacillus, nine isolates were used, and the antagonistic potential was evaluated by the pairing of pathogen and isolate colonies by the circle method. Papaya varieties and/or selections presented all leaves with injury, and Canaan Sunrise Solo and Canaan Golden selections showed the greatest number of injuries per leaf, showing that papaya varieties and/or selections respond differently to the phytopathogen. All plant extracts tested showed inhibitory effect on the mycelial growth of $C$. cassiicola in vitro. Bacillus isolates showed an antagonistic potential on the mycelial growth of the fungus, with $B$. methylotrophicus (Iso 31 and Iso 41) being the most promising as a biological control agent. The results indicate that forms of alternative control of diseases are promising in the management of papaya target-spot.
\end{abstract}

Index terms: Carica papaya L., Azadirachta indica, Cymbopogon nardus, Biocontrol, target spot.

\section{Reação de genótipos de mamoeiro a mancha-alvo e atividade de extratos vegetais e Bacillus spp.sobre Corynespora cassiicola}

Corresponding author:

E-mail: aacrodrigues@outlook.com

Received: September 29, 2016. Accepted: Februrary 14, 2017.

Copyright: All the contents of this journal, except where otherwise noted, is licensed under a Creative Commons Attribution License.
Resumo - A mancha-alvo do mamoeiro, causada pelo fungo Corynespora casiicola, possui ampla distribuição geográfica, causando manchas foliares em vários hospedeiros. O objetivo desta pesquisa foi avaliar o comportamento de variedades/seleções de mamoeiro à ocorrência natural da mancha-alvo e testar o efeito fungitóxico de extratos de nim, citronela e eucalipto, e fungistático de isolados de Bacillus sobre o fungo C. cassiicola in vitro. Para avaliar a ocorrência natural da doença no campo, foram avaliados os sintomas em folhas de 11 variedades e/ou seleções de mamoeiro. A patogenicidade dos isolados foi verificada pela inoculação de plantas em casa de vegetação. Os extratos de nim, citronela e eucalipto foram preparados nas concentrações de 10; 15 e $20 \%$ e vertidos em placas de Petri, contendo discos de micélio de C. cassiicola. Para Bacilllus, foram utilizados nove isolados, e a potencialidade antagonista foi avaliada pelo pareamento de colônias do patógeno e dos isolados, pelo método de círculo. As variedades e seleções de mamoeiro apresentaram a totalidade das folhas com lesões, sendo as seleções Canaã Sunrise Solo e Canaã Golden as que apresentaram maior número de lesões/folhas, mostrando que as variedades/seleções de mamoeiro respondem diferentemente ao fitopatógeno. Todos os extratos vegetais testados apresentaram efeito inibitório sobre o crescimento micelial in vitro de C. cassiicola. Os isolados de Bacillus apresentaram potencial antagônico sobre o crescimento micelial do fungo, sendo os isolados de B. methylotrophicus (Iso 31 e Iso 41) mais promissores como agentes de controle biológico. Estes resultados indicam que formas de controle alternativo de doenças são promissoras no manejo da mancha-alvo do mamoeiro.

Termos para indexação: Carica papaya L., Azadirachta indica, Cymbopogon nardus, Biocontrole, Mancha-alvo.

\footnotetext{
${ }^{1}$ Master in Agroecology, Universidade Estadual do Maranhão / São Luís - MA. Email: dannielle.paz@gmail.com.

${ }^{2}$ Agronomist, PhD, Adjunct Professor, Departamento de Fitotecnia e Fitossanidade, Universidade Estadual do Maranhão / São Luís - MA. Email: gusmao@elo.com.br ${ }^{3}$ Agronomist, PhD, Adjunct Professor, Departamento de Fitotecnia e Fitossanidade, Universidade Estadual do Maranhão / São Luís - MA. Email: aacrodrigues@ outlook.com

${ }^{4}$ Agronomist, PhD in Phytopathology - Universidade Estadual do Maranhão / São Luís - MA. Email: erlenkeila@yahoo.com.br

${ }^{5}$ Agronomist, Universidade Estadual do Maranhão / São Luís - MA. Email: nb.diniz@hotmail.com
} 


\section{Introduction}

Papaya target spot or corynespora leaf blight caused by fungus Corynespora cassiicola (Berk \& Curt.) Wei. has wide geographical distribution, being reported as causing leaf spot in more than 70 host species (TRAN, et al., 2016; DEÓN, et al., 2014; NGHIA et al., 2008; FARR; ROSSMAN, 2006; SILVA et al., 1997). The disease causes damage to a large number of economically important crops in tropical and subtropical countries.

In the state of Maranhão, C. cassiicola was found in several hosts, including papaya (Carica papaya L.) and acerola, causing leaf and fruit problems (SILVA et al., 1997; BITU et al, 2016). It is also mentioned as a pathogen in weeds, such as Commelina benghaleinnsis L.) and Vernonia cinerea (CUTRIM, SILVA, 2003), which are important sources of inoculum, especially under favorable climatic conditions. In papaya, it can affect leaves, stem and fruits, being the symptoms characterized by lesions of pale yellow color ranging from 1 to $2 \mathrm{~mm}$ in diameter, reaching up to $10 \mathrm{~mm}$, with necrotic center. In fruits, lesions are small and rounded, evolving rapidly, affecting the pulp, making the fruit commercially unfeasible (BITU et al., 2016).

Its control is based on the use of fungicides, associated with cultural methods; however, the ideal situation would be the genetic control through the use of resistant cultivars. Genetic resistance is one of the most effective control methods, since the host plant has genetic characteristics that prevent or reduce the incidence and / or severity of the disease (CARVALHO, BARCELLOS, 2012).

Management alternatives have been widely used in the control of diseases because they not only minimize damages to the environment, but also provide healthy food and reduce the use of external inputs and agrochemicals. Among these alternatives, we highlight the use of plant extracts, which have a direct effect on the fungus, altering germination, apressory formation, hyphae growth or spore production, and indirect effect, by activating plant resistance induction mechanisms (MOSSINI; KEMMELMEIER, 2005).

In addition to plant extracts, the use of Bacillus species in biological control programs as phytopathogenic fungus antagonists has been very promising in the management of plant diseases (ANGONESE et al., 2009; SCHISLER et al., 2004). The efficacy of these bacteria occurs through the ability to produce antibiotic compounds with antifungal action and, mainly, to form endospores, providing resistance to environmental changes, allowing storage and maintaining its viability for long periods (SIRIPORNVISAL, 2010; TEJERA et al., 2012) .

Thus, the aim of this research was to evaluate papaya varieties and / or selections as to the natural occurrence of the target spot, and to evaluate the fungitoxic effect and of neem, citronella and eucalyptus extracts and fungistatic effect of Bacillus isolates on fungus
Corynespora cassiicola in vitro.

\section{Material And Methods}

Experiments were conducted at the Laboratory of Phytopathology - São Luís Farm School, belonging to the State University of Maranhão - UEMA, located at $02^{\circ} 35^{\prime} 04.0$ "S and $44^{\circ} 12^{\prime} 33.3^{\prime}$ ' $\mathrm{W}$, in the municipality of São Luís - Maranhão State, Brazil. In order to evaluate the natural occurrence of the target spot, seedlings of the following papaya varieties were used: Sunrise Solo 72/12, Sunrise Solo 783, Sunrise Solo BS, Baixinho de Santa Amália, Golden, Golden Verde Escuro, Canaã Golden, Canaã Sunrise Solo, Gran Golden, Grampola and a local selection of the Solo group ('Green Belt'), used as a control and susceptible to the target spot.

The field experiment was installed in a randomized block design, with four replicates and eleven treatments (varieties), each plot consisting of six plants. The soil of the area was classified as a Sandy Loam soil, with texture ranging from sandy to frank sand. The average temperature in the area is $27^{\circ} \mathrm{C}$ and relative humidity $84 \%$. The characteristics evaluated in the field, under conditions of natural infection with plants at three months of age were: number of leaves / plant; numbers of leaves with lesions; number of lesions / leaf. For the disease analysis, two leaves were removed from the median third per plant of each variety to count the number of leaf lesions, photographic registration and isolation to confirm the disease causal agent, disease and pathogen characterization.

For pathogenicity confirmation, seedlings of the Sunrise Havaí variety were planted in pots containing sterilized soil and bovine manure $(3: 1 \mathrm{v} / \mathrm{v})$ and kept in greenhouse. In the preparation of the inoculum, the obtained isolate was transferred to Petri dishes containing PDA (Potato-Dextrose-Agar) culture medium and incubated for seven days $\left(25 \pm 2{ }^{\circ} \mathrm{C}\right)$. After this period, $20 \mathrm{~mL}$ of distilled water were added per dish, and colonies were scraped to release the conidia, and then the suspension was adjusted to $1 \times 10^{4}$ conidia. $\mathrm{mL}^{-1}$, with the aid of a Neubauer chamber. Inoculation was carried out 60 days after planting by the spraying method and kept in a humid chamber for 48 hours. Disease evaluation was performed 30 days after inoculation through the level of incidence of symptoms.

For the characterization of the C. cassiicola isolate, the pathogen was re-isolated from the lesions, and fragments were placed in Petri dishes containing PDA medium and maintained at room temperature $(25 \pm$ $2{ }^{\circ} \mathrm{C}$ ). The identification of the isolate was made according to morphological aspects with the aid of microcultures (MENEZES; ASSIS, 2004). Measurements of width, length and number of septa of 100 conidia observed under optical microscope and with the aid of a micrometer eyepiece were performed. 
In order to evaluate the inhibitory action of plant extracts and Bacillus isolates on C. cassiicola, two in vitro experiments were carried out. In the first trial, neem (Azadirachta indica A. Juss.), Citronella (Cymbopogon winterianus Jowitt) and eucalyptus (Eucalyptus citriodora Hook) extracts were obtained from UEMA Farm School. To prepare the $10 \%$ aqueous extracts, $5 \mathrm{~g}$ of plant material (fresh and healthy leaves) were ground in $50 \mathrm{ml}$ of distilled water and sterilized in the blender for 10 minutes, then the material was filtered through double gauze, filter paper and Filtration membrane with $0.22 \mu \mathrm{m}$ porosity, coupled to a syringe (SILVA, 2007). After extraction, extracts were added to the PDA medium at concentrations of $1 ; 1.5$ and $2 \%$, and were then poured into Petri dishes. Mycelium disk of $6 \mathrm{~mm}$ in diameter of 10-days-old C. cassiicola were transferred to the center of Petri dishes and kept at room temperature $\left(25 \pm 2{ }^{\circ} \mathrm{C}\right)$.

In the second assay, nine Bacillus isolates were obtained from the UEMA's Phytopathology Laboratory Collection, which were molecularly identified as: Bacillus methylotrophicus - Iso12, Iso 22, Iso 22 ', Iso 31, Iso 40, Iso 41, Iso 45; B. thuringiensis - Iso 35; B. amyloliquefaciens - Iso 47. In the evaluation of the antagonistic potential, the pairing of pathogen and isolate colonies were evaluated by the circle method. A $6 \mathrm{~mm}$ diameter mycelial disc with $C$. cassiicola structures was transferred to the center of Petri dishes containing PDA culture medium. With the aid of a platinum loop, bacterial isolates were inoculated into a circle of approximately $5 \mathrm{~cm}$ at the edges of the culture medium. Dishes were kept at room temperature $(25 \pm 2$ $\left.{ }^{\circ} \mathrm{C}\right)$ (MARIANO; SILVEIRA, 2005).

The evaluation of mycelial growth was carried out on the $10^{\text {th }}$ day for plant extracts, and on the $5^{\text {th }}, 7^{\text {th }}$, $10^{\text {th }}$ and $12^{\text {th }}$ day for Bacillus isolates, by measuring the radial growth of the colony on two orthogonal axes. Percent inhibition of mycelial growth was calculated (EDIGINGTON et al., 1971).

The first trial showed completely randomized design (CRD), in a $3 \times 4$ factorial scheme (treatments $\mathrm{x}$ concentration of extracts) with four replicates, while in the second, a completely randomized design with nine of Bacillus sp. and four replicates. Control was composed of dishes containing PDA medium with the phytopathogen. The averages were compared by the Tukey test at $5 \%$ probability level.

\section{Results And Discussion}

Plants inoculated with the pathogen after the incubation period showed target spot symptoms, confirming the fungus pathogenicity. Symptoms were initiated by white spots, with yellowish halo, evolving to circular spots of brown coloration. These symptoms coincide with those described in literature on papaya plants (KNAAK et al., 2010; SILVA, 2011; BITU, 2016).

In the evaluation of diseased plants under field conditions (Table 1), the percentage of diseased leaves was very similar in all varieties, indicating that the incidence was generalized, being favored by the hot and humid climate. Grampola, Canaã Sunrise Solo, Gran Golden, Sunrise Solo 72/12, Golden Verde Escuro varieties did not differ statistically from the Green Belt control variety, presenting lower percentage of diseased leaves. Golden variety presented percentage of $100 \%$ of diseased leaves. For the number of lesions per leaf, Canaã Sunrise Solo and Canaã Golden varieties obtained greater amount of lesions, of the order of 98.75 and $77.12 \%$, respectively, differing from the others.

Table 1. Evaluation of the target spot in three-month-old papaya varieties at the UEMAFarm School, São Luís - Maranhão.

\begin{tabular}{lccc}
\hline \multicolumn{1}{c}{ Variety } & $\begin{array}{c}\text { Number of leaves } \\
\text { per plant }\end{array}$ & $\begin{array}{c}\text { Diseased } \\
\text { leaves (\%) }\end{array}$ & $\begin{array}{c}\text { Number of lesions per } \\
\text { leaf }\end{array}$ \\
\hline Grampola & $12.121 \mathrm{a}$ & $90.75 \mathrm{~b}$ & $20.95 \mathrm{~b}$ \\
Sunrise Solo 783 & $12.00 \mathrm{a}$ & $94.75 \mathrm{ab}$ & $25.00 \mathrm{~b}$ \\
Canaã Sunrise Solo & $11.87 \mathrm{a}$ & $92.67 \mathrm{~b}$ & $98.75 \mathrm{a}$ \\
Sunrise Solo BS & $11.75 \mathrm{a}$ & $96.76 \mathrm{ab}$ & $32.75 \mathrm{~b}$ \\
Gran Golden & $11.37 \mathrm{ab}$ & $92.35 \mathrm{~b}$ & $28.50 \mathrm{~b}$ \\
Baixinho de Santa Amália & $10.87 \mathrm{ab}$ & $93.10 \mathrm{ab}$ & $29.37 \mathrm{~b}$ \\
Golden & $10.62 \mathrm{ab}$ & $100.00 \mathrm{a}$ & $17.87 \mathrm{~b}$ \\
Sunrise Solo 72/12 & $10.62 \mathrm{ab}$ & $91.80 \mathrm{~b}$ & $22.50 \mathrm{~b}$ \\
Canaã Golden & $10.50 \mathrm{ab}$ & $92.85 \mathrm{ab}$ & $77.12 \mathrm{a}$ \\
Golden Verde Escuro & $8.87 \mathrm{~b}$ & $91.54 \mathrm{~b}$ & $19.75 \mathrm{~b}$ \\
Cinturão Verde (Control) & $10.87 \mathrm{ab}$ & $89.69 \mathrm{~b}$ & $23.91 \mathrm{~b}$ \\
\hline VC (\%) & 9.26 & 3.13 & 33.01 \\
SMD & 2.52 & 7.30 & 37.50 \\
\hline
\end{tabular}

${ }^{1}$ Means followed by the same letters (in the column) do not differ statistically from each other by the Tukey test at the $5 \%$ probability level. 


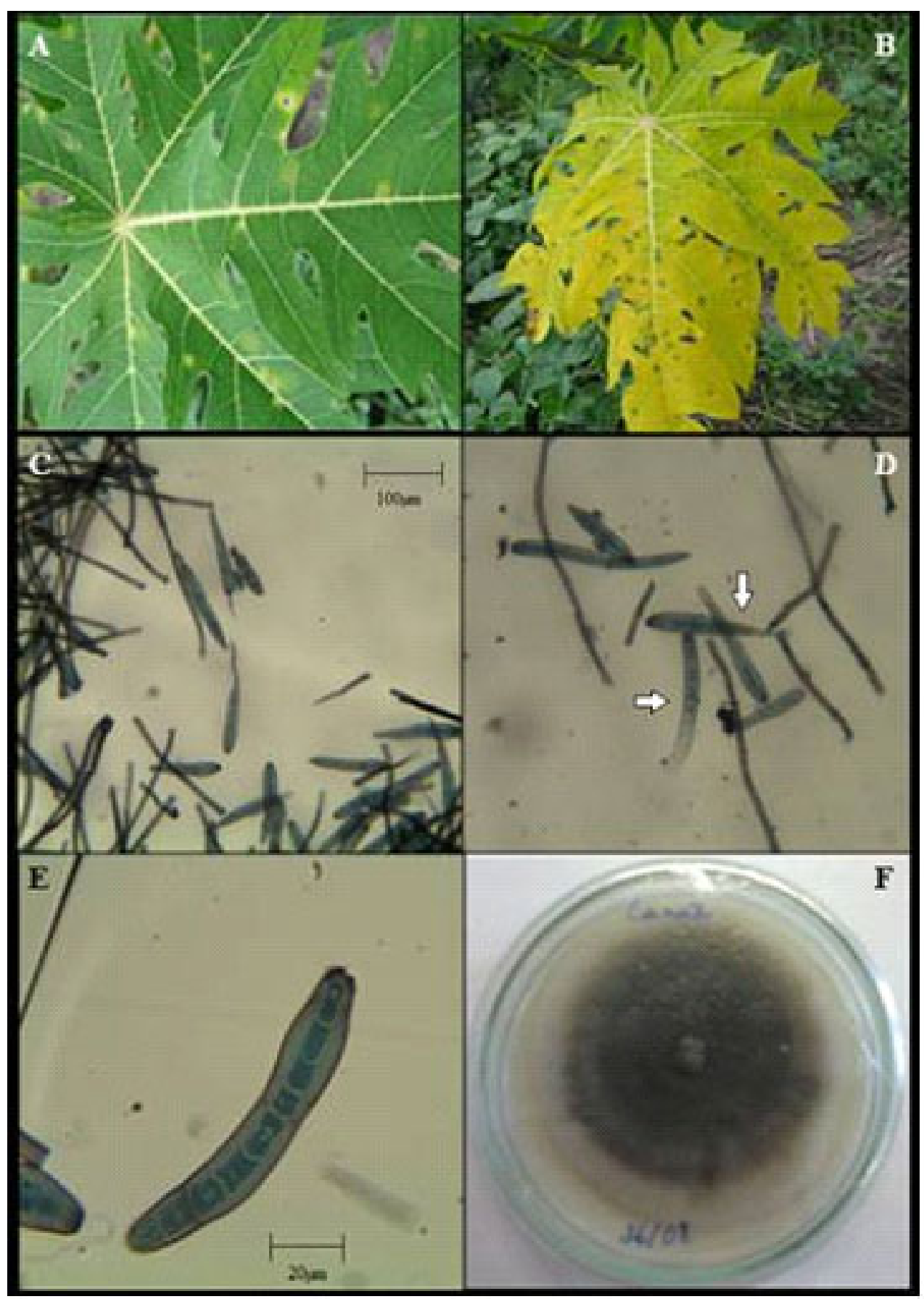

Figure 1. Characteristic lesions of C. cassiicola on papaya leaves: Initial symptoms (A) and generalized lesions on older leaves, showing strong yellowing (B); Structures of fungus C. cassiicola visualized with the aid of optical microscope with eyepiece of 10x and objective of 10x and 40x: (C) Conidia of varied sizes; (D) Straight or slightly curved shape; (E) Dark halo at the extremity; Aspect of the colony in PDA medium (F). 
Within C. cassiicola species, isolates from different hosts may differ in pathogenicity, some of which may have a greater or lesser range of hosts. Oliveira et al. (2007) demonstrated the high pathogen non-specificity as well as the variation in susceptibility reaction according to the host, in which papaya was the most susceptible. Breton et al. (2000) also verified different reactions presented by different papaya varieties and / or selections, and genetic variability among cultivars.

Although statistically differing only from Canaã Sunrise Solo and Canaã Golden varieties, the Golden variety even presenting all leaves with lesions had lower number of lesions per leaf when compared to the others (Table 1). These results corroborate results of Venturini et al. (2014), who studied the natural infection of $C$. cassiicola in papaya under greenhouse conditions and verified that the Golden variety had low natural incidence of the fungus. The symptoms of the disease observed in papaya in the field are shown in Figure 1. Small leaf lesions of around 2-3 mm, rounded, white and surrounded by a yellow halo (Figure 1A) were observed. With the disease evolution, lesions on the older leaves reached 6 $\mathrm{mm}$, presenting irregular shape, brown tonality, becoming necrotic, showing yellowing (Figure 1B), causing premature defoliation, and in some cases plant death.
Fungus C. cassiicola in PDA medium initially showed white and flocculent mycelium, later acquiring the dark gray color, becoming a black olive tangle (Figure $1 \mathrm{~F})$.

Conidia presented morphology corresponding to the genus Corynespora, with straight or slightly curved shape, septate and showing dark halo at the extremity (Figure 1D). In the measurement of 100 conidia originating from the mycelial growth of $C$. cassiicola in PDA medium, presenting dimensions varying from $13.50-21.90 \mu \mathrm{m}$ in width and $76.76-165.26 \mu \mathrm{m}$ in length, with mean value of $16.54 \times 98.15 \mu \mathrm{m}$ (Figure 1C), and number of septa ranging from 3-8 (Figures 1E).

The symptoms observed here in plants and in vitro are similar to those described in literature (LIBERATO; McTAGGART, 2006; SILVA, 2011; SNOW; BERGGREN Jr., 1989), proving the fungus identity.

The results of tests with plant extracts showed that all treatments were able to inhibit the mycelial growth of the pathogen in the three concentrations evaluated (Table 2). It was verified that for neem and eucalyptus extracts, the increase in the inhibition was proportional to the increase of concentrations, whereas for the citronella extract, efficiency was similar.

Table 2. Mean colony diameter (CD) and percentage of mycelial growth inhibition (PGI) of C. cassiicola submitted to different concentrations of neem, citronella and eucalyptus extracts after ten days of incubation at $25 \pm 2{ }^{\circ} \mathrm{C}$ in PDA medium .

\begin{tabular}{|c|c|c|c|c|c|c|c|}
\hline \multirow{3}{*}{ Treatments } & \multicolumn{7}{|c|}{ Concentration } \\
\hline & \multicolumn{2}{|c|}{$1 \%$} & \multicolumn{2}{|c|}{$1.5 \%$} & \multicolumn{2}{|c|}{$2 \%$} & \multirow{2}{*}{ Mean } \\
\hline & CD (cm) & PGI (\%) & CD (cm) & PGI (\%) & CD (cm) & PGI (\%) & \\
\hline Neem & $7.66 \mathrm{bA}^{*}$ & 14.88 & $7.07 \mathrm{bAB}$ & 21.44 & $6.52 \mathrm{bB}$ & 27.56 & $7.08 \mathrm{~b}$ \\
\hline Citronella & $5.71 \mathrm{cA}$ & 36.56 & $6.08 \mathrm{cA}$ & 32.44 & $5.95 \mathrm{bA}$ & 34.22 & $5.91 \mathrm{~d}$ \\
\hline Eucalyptus & $6.92 \mathrm{bA}$ & 23.11 & $6.85 \mathrm{bA}$ & 23.89 & $5.86 \mathrm{bB}$ & 34.89 & $6.54 \mathrm{c}$ \\
\hline Control & $9.00 \mathrm{aA}$ & - & $9.00 \mathrm{aA}$ & - & $9.00 \mathrm{aA}$ & - & $9.00 \mathrm{a}$ \\
\hline Mean & $7.32 \mathrm{a}$ & & $7.25 \mathrm{a}$ & & $6.83 \mathrm{~b}$ & & 7.13 \\
\hline
\end{tabular}

* Averages followed by the same lowercase letter (columns) and upper case (lines) do not differ by the Tukey test at 5\% probability. VC\% 5.61 ; SMD 0.76 (columns) and 0.69 (lines).

Tests involving the use of extracts and residues of neem leaves showed inhibition of the vegetative growth of many pathogens of the genus Fusarium sp., such as F. oxysporum f. sp. ciceri (Fock.), F. oxysporum f. sp. cepae (Hanzawa.), F. oxysporum (Snyder \& Hansen), $F$. solani Mart., as well as other fungi belonging to other genera such as Aspergillus sp., Sclerotinia sp., Pyricularia sp., Rhizoctonia sp., Penicillium sp. (MOSSINI; KEMMELINGER, 2005) and Colletotrichum gloeosporioides (OGBEBOR et al., 2007). Reports have confirmed the potential of the antifungal activity of this plant, demonstrating its efficiency in the control of diseases, mainly those caused by fungi, showing their fungitoxic and fungistatic effects and use as a suppressor of phytopathogenic fungi (MOSSINI; KEMMELMEIER, 2005).
The mean growth diameter showed that the citronella extract statistically differed from the other extracts with $5.71 \mathrm{~cm}$ (Table 2), differing from the results obtained by Moreira et al. (2008), in which fractions obtained from methanolic and ethanolic citronella extracts did not promote direct fungitoxic activity against Colletotrichum lagenarium. This result may be associated to the extraction method, since they used ethyl and methyl alcohol as extracting solvent, and also to the fungus, because in the present work, the action was performed against C. cassiicola. 
Comparing the different eucalyptus extract concentrations, it was observed that the highest concentration (2\%) statistically differed from the others, providing smaller diameter of the C. cassiicola colony. The effectiveness of eucalyptus extract in the fungal inhibition was also verified by Ferreira et al. (2015), who found that concentrations from $10 \%$ inhibited $100 \%$ the mycelial growth of Fusarium oxysporum f. sp. passiflorae in in vitro assays.
In relation to the Bacillus isolates, the results show that all isolates presented a fungistatic characteristic to the pathogen, reducing the antagonistic potential with the evaluation days, except for Iso 31, which maintained a constant inhibition average, not significantly differing in the evaluated periods, behaving as the most efficient isolate in inhibiting the mycelial growth of $C$. cassiicola (Table 3).

Table 3. Effect of Bacillus isolates on in vitro mycelial growth of C. cassiicola in PDA medium, evaluated at the $5^{\text {th }}$, $7^{\text {th }}, 10^{\text {th }}$ and $12^{\text {th }}$ days of incubation.

\begin{tabular}{llcccccc}
\hline & \multirow{2}{*}{ Treatments } & \multicolumn{4}{c}{ Colony diameter (cm) } & & PGI \\
\cline { 3 - 6 } & & $\mathbf{5 ~ d a y s}$ & $\mathbf{7 ~ d a y s}$ & $\mathbf{1 0}$ days & $\mathbf{1 2}$ days & Mean & $\mathbf{( \% )}$ \\
\hline ISO 12 & B.methylotrophicus & $3.17 \mathrm{aB}$ & $5.19 \mathrm{~b}$ & $6.41 \mathrm{abA}$ & $6.95 \mathrm{abcA}$ & $5.19 \mathrm{~b}$ & 13.98 \\
ISO 22 & B. methylotrophicus & $3.27 \mathrm{aC}$ & $5.11 \mathrm{~b}$ & $5.66 \mathrm{abcB}$ & $7.50 \mathrm{abA}$ & $5.11 \mathrm{~b}$ & 7.17 \\
ISO 22, & B. methylotrophicus & $3.06 \mathrm{aB}$ & $4.05 \mathrm{abB}$ & $5.41 \mathrm{bcA}$ & $5.63 \mathrm{cdA}$ & $4.54 \mathrm{bc}$ & 30.32 \\
ISO 31 & B. methylotrophicus & $2.37 \mathrm{aA}$ & $2.45 \mathrm{cA}$ & $2.66 \mathrm{eA}$ & $2.93 \mathrm{eA}$ & $2.60 \mathrm{e}$ & 63.36 \\
ISO 35 & B. thuringiensis & $2.60 \mathrm{aC}$ & $3.38 \mathrm{bcBC}$ & $4.25 \mathrm{cdB}$ & $5.57 \mathrm{cdA}$ & $3.95 \mathrm{~cd}$ & 31.06 \\
ISO 40 & B. methylotrophicus & $3.30 \mathrm{aC}$ & $4.23 \mathrm{abBC}$ & $5.37 \mathrm{bcAB}$ & $6.15 \mathrm{bcA}$ & $4.76 \mathrm{~b}$ & 23.88 \\
ISO 41 & B. methylotrophicus & $2.67 \mathrm{aB}$ & $3.03 \mathrm{bcAB}$ & $3.72 \mathrm{deAB}$ & $4.17 \mathrm{deA}$ & $3.40 \mathrm{~d}$ & 48.39 \\
ISO 45 & B. methylotrophicus & $3.15 \mathrm{aB}$ & $4.16 \mathrm{abB}$ & $5.81 \mathrm{abA}$ & $6.85 \mathrm{abcA}$ & $4.99 \mathrm{~b}$ & 15.22 \\
ISO 47 & B. amyloliquefaciens & $3.10 \mathrm{aC}$ & $3.96 \mathrm{abC}$ & $5.80 \mathrm{abB}$ & $7.45 \mathrm{abA}$ & $5.07 \mathrm{~b}$ & 7.79 \\
Control & & $3.82 \mathrm{aC}$ & $5.25 \mathrm{aB}$ & $7.15 \mathrm{aA}$ & $8.08 \mathrm{Aa}$ & $6.07 \mathrm{a}$ & 0 \\
\hline Mean & & $3.05 \mathrm{~d}$ & $3.88 \mathrm{c}$ & $5.22 \mathrm{~b}$ & $6.13 \mathrm{a}$ & 4.57 &
\end{tabular}

* Averages followed by the same lowercase letter (columns) and upper case (lines) do not differ by the Tukey test at 5\% probability. VC\% 14.38 ; SMD 1.49 (columns) and 1.21 (lines). PGI = percentage of mycelial growth inhibition.

In the evaluation of the antagonistic potential of Bacillus isolates, no significant differences among treatments was observed on the fifth day. On the seventh day of evaluation, Iso 31 showed the lowest fungal growth $(2.45 \mathrm{~cm})$, followed by Iso 41 and Iso 35 , statistically differing from the other isolates. On the other days, Iso 41 maintained its colony growth averages statistically equal to Iso 31 , reaching inhibition percentage of $48.39 \%$ (Table 3).

The results showed that Iso 31 and Iso 41 had high inhibition percentage in relation to the other treatments, 63.36 and $48.39 \%$ in phytopathogen inhibition, compared to Iso 22 and Iso 47 isolates, which had the lowest inhibition percentages ( 7.17 and $7.79 \%$, respectively).

These results are in agreement with Ferraz et al. (2008), who verified the biocontrol action of B. cereus in the control of the tomato target spot, with reduction of $50 \%$ in the mean number of lesions per leaves in plants from microbiolized seeds when they were artificially inoculated with C. cassiicola.
The microorganisms involved in biological control usually act by antibiosis, producing metabolites that lead to complete lysis and dissolution of the cell structure, regardless of physical contact among microorganisms; thus, the inhibitory effect of Bacillus species is related to the production of antibiotics secreting commercially important metabolites such as chitinase and glucanase enzymes (KNAAK et al., 2010).

The action of Bacillus through antibiosis has shown to be promising in the biological control of several pathogens, confirming the results found in this work. Silva et al. (2014) in rice study observed that spraying with Bacillus promoted a biocontrol effect on Curvularia lunata. Angonese et al. (2009) tested the fungistatic effect of Bacillus spp. isolates on phytopathogenic fungi and observed their ability to antagonize Alternaria spp., Botrytis spp., Fusarium oxysporum and Colletotrichum spp., showing the antagonistic potential of this genus under a range of phytopathogens. Tejera et al. (2012) verified that Bacillus isolates promoted high inhibition on fungi Curvularia and $P$. grisea. 


\section{Conclusion}

Papaya varieties studied respond differently to the action of the fungus Corynespora cassiicola, in natural infection in the field. Neem, citronella and eucalyptus extracts are efficient in inhibiting mycelial growth of the fungus and Bacillus isolates presented antagonistic potential under in vitro mycelial growth of $C$. cassiicola, being able to be used in papaya corynespora leaf blight management programs.

\section{References}

ANGONESE, M.T.; DELLA GIUSTINA JÚNIOR, L.H.P.; PANSERA, M.R.; PAGNO, R.S.; MEZZOMO, F.; ZORZI, E.; PEREIRA, C.O.F.; RIBEIRO, R.T.S. Efeito fungistático de Bacillus spp. sobre fungos fitopatogênicos. Revista Brasileira de Agroecologia, Porto Alegre, v.4, n. 2, p. $96-100,2009$.

BITU, P.I.M.; SANTOS, L.V.S.; RODRIGUES, A.A.C.; BRAUN, H.; MONTEIRO, O.S.; FERRAZ JUNIOR, A.S.L.; SILVA, M.R.M.Alternative control of Corynespora cassiicola in papaya seedlings and fruits by Cinnamomum zeylanicum essential oil. African Journal of Agricultural Research, Nairobi, v.11, p.1862-1871, 2016.

BRETON, F.; SANIER, C.; D'AUZAC. Role of cassiicolon, a rost-selective toxin, in pathogenicity of Corynespora cassiicola, causal of a leaf fall disease of Heave. Journal of Rubber Research, Malaysia, v.3, n.2, p.115-128, 2000.

CARVALHO, N.L.; BARCELLOS, A.L. Adoção do manejo integrado de pragas baseado na percepção e educação ambiental. Revista Eletrônica em Gestão, Educação e Tecnologia Ambiental, Santa Maria, v.5, n.5, p.749-766, 2012.

CUTRIM, F.A.; SILVA, G.S. Patogenicidade de Corynespora cassiicola a diferentes espécies de plantas. Fitopatologia Brasileira, Brasília, DF, v.28, p.193-194, 2003.

DEON, M.; FUMANAL, B.; GIMENEZ, S.; BIEYSSE, D.; OLIVEIRA, R.R.; SHUIB, S.S.; BRETON, F.; ELUMALAI, S.; VIDA, J.B.; SEGUIN, M.; LEROY, T.; ROECKEL-DREVET, P.; PUJADE-RENAUD, P. Diversity of the cassiicolin gene in Corynespora cassiicola and relation with the pathogenicity in Hevea brasiliensis. Fungal Biology, Oxford, n.118, v.1, p.32-47.2014.

EDIGINGTON, L.V.; KHEW, K.L.; BARRON, G.L. Fungitoxic spectrum of benzimidazoles compounds. Phytopathology, St.Paul, v.61, p.42-44, 1971.
FARR, D.F.; ROSSMAN, A.Y. Fungal databases, systematic mycology and microbiology laboratory. Bethesvile: USDA, 2006. Disponível em: $<$ http://nt.arsgrin.gov/fungaldatabases $>$. Acesso em: 23 ago. 2014.

FERRAZ, H.G.M.; ROMEIRO, R.S.; GARCIA, F.A.O.; SOUZA, A.N. Biocontrole da mancha-alvo do tomateiro por Bacillus cereus em função do modo de dispensa na planta. Revista Trópica - Ciências Agrárias e Biológicas, Chapadinha, v.2, n.2, p.35, 2008.

FERREIRA, R.B.; RODRIGUES, A.A.C.; MORAES, F.H.R.; SILVA, E.K.C.; NASCIMENTO, I.O. Resíduos orgânicos no controle de Fusarium oxysporum f.sp. passiflorae em maracujazeiro amarelo (Passiflora edulis f. flavicarpa). Acta Biologica Colombiana, Bogotá, v.20, n.3, p.111-120, 2015.

KNAAK, N.; AZAMBUJA, A.O.; LUCHO, A.P.R.; BERLITZ, D.L.; FIUZA, L.M. Interações de Bacillus thuringiensis e o controle de fitopatógenos. Biotecnologia Ciência \& Desenvolvimento, Brasília, DF, n.38, p.48-53, 2010.

LIBERATO, J.R.; MCTAGGART, A.R. Corynespora brown spot of Papaya (Corynespora cassiicola). 2006. Disponível em: <http://www.padil.gov.au/pestsanddiseases/ Pest/Main/136590\#>. Acesso em: 03 mar. 2015 .

MARIANO R.L.R.; SILVEIRA, E.B. Manual de práticas em fitobacteriologia. 2.ed. Recife: UFRPE, 2005. 184p.

MENEZES, M.; ASSIS, J.P. Guia prático de fungos fitopatogênicos. Recife: UFRPE - Impressa Universitária, 2004. $106 \mathrm{p}$.

MOREIRA, C.G.A.; SCHWAN-ESTRADA, K.R.F.; BONALDO, S.M.; STANGARLIN, J.R.; CRUZ, M.E.S. Caracterização parcial de frações obtidas de extratos de Cymbopogon nardus com atividade elicitora de fitoalexinas em sorgo e soja e efeito sobre Colletotrichum lagenarium. Summa Phytopathologica, Botucatu, v.34, n.4, p.332-337, 2008.

MOSSINI, S.A.G.; KEMMELMEIER, C. A árvore Nim (Azadirachta indica A.Juss): múltiplos usos. Maringá. Acta Farmaceutica Bonaerense, Buenos Aires, v.24, n.1, p.139-148, 2005.

NGHIA, N.; KADIR, J.; SUNDERASAN, E.; PUAD ABDULLAH, M.; MALIK, A.; NAPIS, S. Morphological and Inter Simple Sequence Repeat (ISSR) Markers Analyses of Corynespora cassiicola Isolates from Rubber Plantations in Malaysia. Mycopathologia, Den Haag, v.166, n.4, p.189-201, 2008. 
OGBEBOR, N.O.; ADEKUNLE, A.T.; ANOBAKHARE, D.A. Inhibition of Colletotrichum gloeosporioides (Penz.) Sacc. casual organism of rubber (Heave brasiliensis Muell. Arg.) leaf spot using plant extract. African Journal of Biotecnology, Naiorobi, v.6, n.3, p.213-218, 2007.

OLIVEIRA, R.R.; VIDA, J.B.; TESSMANN, D.J., AGUIAR, B.M.; CAIXETA, M.P.; BARBOZA, A.A.L. Patogenicidade de isolados de Corynespora cassiicola a diferentes espécies de plantas. Summa Phytopathologica, Botucatu, v.33, n.3, p.297-299, 2007.

SCHISLER, D.A.; SLININGER, J.P.; BEHLE, W.R.; JACKSON, A.M. Formulation of Bacillus spp.for biological control of plant diseases. Phytopathology, St.Paul, v.94, p.1267-1271, 2004.

SILVA, G.S. Guia prático para identificação das principais doenças do mamoeiro no estado do maranhão. São Luís: Editora UEMA, 2011. p.19.

SILVA, G.S., RODRIGUES, A.A.C., SOARES JÚNIOR, A.C. Mancha de Corynespora em acerola (Malpighia glabra). Fitopatologia Brasileira, Brasília, DF, v.22, p.452.1997.

SILVA, J.C. Uso de óleos essenciais, extratos vegetais e indutores de resistência no controle alternativos do mal-do-panamá da bananeira. 2007. 68f. Dissertação (Mestrado em Produção Vegetal) - Universidade Federal de Alagoas, Rio Largo, 2007.
SILVA, M.S.B.S.; RODRIGUES, A.A.C; OLIVEIRA, L.J.M.G.; SILVA, E.K.C.; PEREIRA, T.S. Sanidade de sementes de arroz, biocontrole, caracterização e transmissão de Curvularia lunata em semente-plântula de arroz. Revista Ceres, Viçosa, MG, v.61, n.4, p.511517, 2014.

SIRIPORNVISAL, S. Biocontrol Efficacy of Bacillus subtilis BCB3-19 against Tomato Gray Mold. KMITL Science and Technology Journal, Thailand, v.10, n.2, p.37-44, 2010.

SNOW, J.P., BERGGREN JR, G.T. Target spot: In: SINCLAIR, J.B.; BACKMAN, P.A. Compendium of soybean diseases. $3^{\text {rd }}$ ed. St Paul: American Phytopathological Society, 1989. p.27-28.

TEJERA, B.; HEYDRICH, M.; ROJAS, M.M. Antagonismo de Bacillus spp.frente a hongos fitopatógenos del cultivo del arroz (Oryza sativa L.). Revista de Protección Vegetal, La Habana, v.27, n.2, p.117-122, 2012.

TRAN, D.M.; CLÉMENT-DEMANGE, A.; DÉON, M., GARCIA, D.; LE GUEN, V.; CLÉMENT-VIDAL, A.; SOUMAHORO, M.; MASSON, A.; LABEL, P.; LE, M.T.; PUJADE-RENAUD, V. Genetic determinism of sensitivity to Corynespora cassiicola exudates in rubber tree (Hevea brasiliensis). Plos One, Pisa, v.13, n.11, p.125, 2016.

VENTURINI, M.T.; SANTOS, L.C.; SANTOS, T.R.; LUZ, E.D.M.N. Natural infection by Corynespora cassiicola in papaya accessions. Summa Phytopathologica, Botucatu, v.40, n.3, p.284-287, 2014. 